\title{
LETTERS
}

\section{Transmission of coronavirus by nebulizer: a serious, underappreciated risk}

This letter is in response to the news article by Wendy Glauser. ${ }^{1}$ The current pandemic of coronavirus disease 2019 (COVID-19) cases demands greater infection control precautions. Nebulizers generate aerosol particles in the size of 1-5 $\mu \mathrm{m}$, which can carry bacteria and viruses into the deep lung. The risk of infection transmission via droplet nuclei and aerosols may increase during nebulizer treatments because of the potential to generate a high volume of respiratory aerosols that may be propelled over a longer distance than is involved in a natural dispersion pattern. ${ }^{2}$ Furthermore, the larger particles may stimulate both patients' and bystanders' cough and thus increase the risk of spreading the disease. ${ }^{3}$ There is a possibility that nebulizer therapy in patients with COVID-19 infection can transmit potentially viable coronavirus to susceptible bystander hosts.

In recent years there has been a welcome shift, in some centres, from the use of nebulizers to metered-dose inhalers with valved holding chambers. For example, in Alberta, Canada, any order for nebulizer is now restricted and a nebulizer is to be used only in the following situations:
- Patients with severe, life-threatening respiratory disease (e.g., those with severe or impending respiratory arrest, or those with hypoventilation or ventilation compromise, continuous nebulization, end-stage chronic obstructive pulmonary disease, cystic fibrosis); or

- Patients who are uncooperative or are unable to follow the directions required for using a metered-dose inhaler with spacer; or

- Patients with a history of poor response to metered-dose inhaler with spacer.

However, despite a large body of evidence suggesting their lack of superiority or inferiority compared with metereddose inhalers with valved holding chambers, ${ }^{4}$ nebulizers are still widely used in many health care facilities (especially in the United States).

Given the current outbreak of COVID19, Alberta Health Services in Canada has now requested that any plan or order for nebulizer therapy be reconsidered. To reduce the risk of transmission of all infectious respiratory illnesses in health care facilities, we would encourage all caregivers in all other provinces to align with the above restrictions and seriously consider avoiding the use of nebulizers. Keeping our patients and staff safe should be our priority.

\section{Israel Amirav MD}

Pediatric respirologist, University of Alberta, Edmonton, Alta.; Dana-Dwek Childrens' Hospital, Tel Aviv Medical

Center, Tel Aviv, Israel

\section{Michael T. Newhouse MD MSc}

Respirologist, McMaster University, Hamilton, Ont.

Cite as: CMAJ 2020 March 30;192:E346. doi: $10.1503 / \mathrm{cmaj} .75066$

\section{References}

1. Glauser W. Communication, transparency key as Canada faces new coronavirus threat. CMAJ 2020;192:E171-2.

2. Tang JW, Li Y, Eames I, et al. Factors involved in the aerosol transmission of infection and control of ventilation in healthcare premises. $J$ Hosp Infect 2006;64:100-14.

3. Prevention and control of influenza during a pandemic for all healthcare settings. Annex F. Ottawa: Public Health Agency of Canada; 2011. Available: www.phac-aspc.gc.ca/cpip-pclcpi/ assets/pdf/ann-f-eng.pdf (accessed 2020 Mar. 1).

4. Cates CJ, Crilly JA, Rowe BH. Holding chambers (spacers) versus nebulisers for beta-agonist treatment of acute asthma. Cochrane Database Syst Rev 2006;(2):CD000052.

Competing interests: Michael Newhouse is employed by InspiRx Pharmaceuticals Inc. as the Chief Medical Officer and has patents through InspiRx Pharmaceuticals Inc. (6,470.882; 8,119,016; D 689,602; D 685,085; and D 686725; Pending: US 2012/0318261 and 2012/0318265). No other competing interests were declared. 